\title{
PENINGKATAN HASIL BELAJAR MATEMATIKA SISWA MELALUI PENDEKATAN MATEMATIKA REALISTIK PADA OPERASI HITUNG DI KELAS I SD UNGGUL TERPADU PADANG PARIAMAN
}

\author{
Januarti
}

Dinas Pendidikan Padang Pariaman

\begin{abstract}
Abstratc
At grade I SD Unggul Terpadu Padang Pariaman, teacher used to teach mathematics traditionally. This study is aimed to improve students' learning achievement by implementing Realistic Mathematics Education approach. This is a classroom action research consisting of planning, implementation, observation, and reflection. Data were collected through observation, interview, and test. In cycle, average score of students' learning achievement is 77.2 and become 88.2 in cycle II. Hence, Realistic Mathematics Education can improve students' learning achievement.
\end{abstract}

Keyword: realistic mathematics education, learning achievement

Copyright (C) 2017 IICET - All Rights Reserved

Indonesian Institute for Counseling, Education and Therapy (IICET)

\section{PENDAHULUAN}

Pendidikan di Sekolah Dasar (SD) merupakan pondasi yang pertama untuk mencapai suksesnya pendidikan selanjutnya, salah satunya pada mata pelajaran Matematika. Matematika merupakan ilmu universal yang mendasari perkembangan teknologi modern, mempunyai peranan penting dalam berbagai disiplin dan memajukan daya pikir manusia. Salah satu karakteristik matematika adalah mempunyai sifat yang abstrak, ini menyebabkan banyak siswa mengalami kesulitan dalam belajar Matematika. Hal lain yang menyebabkan sulitnya matematika bagi siswa adalah karena pembelajaran matematika kurang bermakna, jadi pemahaman konsep yang benar sangatlah penting. Untuk memahami konsep yang baru, diperlukan prasyarat konsep sebelumnya agar pembelajaran matematika dimengerti oleh siswa, maka perlu penanaman konsep awal yang benar dari guru terutama guru SD.

Penerapam konsep matematika terutama materi operasi perkalian bilangan cacah dalam kehidupan seharihari dapat dilakukan dengan strategi pembelajaran yang mengaitkan dengan dunia nyata sebagai titik tolak dalam belajar matematika, yang dikenal dengan pendekatan matematika realistik. Pembelajaran operasi perkalian 
bilangan cacah dengan pendekatan matematika realistik, akan memberikan kesempatan kepada siswa untuk menemukan dan mengkonstruksi kembali konsep-konsep matematika sehingga siswa mempunyai konsep pengertian yang kuat. Pembelajaran matematika haruslah bermakna bagi siswa, supaya siswa tidak mengalami kesulitan dalam mengaplikasikan matematika dalam situasi kehidupan nyata siswa. Guru dalam mengajar matematika di kelas harus mengaitkan pembelajarannya dengan skema yang telah dimiliki oleh siswa dan siswa harus diberikan kesempatan untuk menemukan kembali dan mengkonstruksi sendiri ide-ide matematika tersebut. Namun dalam penyampaian pembelajaran matematika umumnya guru tidak mengaitkan dengan skema yang telah dimiliki oleh siswa dan siswa kurang diberikan kesempatan untuk menemukan kembali dan mengkonstruksi sendiri ide-ide matematika, sehingga menyebabkan siswa belajar secara pasif.

Dari hasil observasi dan wawancara yang penulis laksanakan di SD Unggul Terpadu Padang Pariaman di kelas I, siswa kesulitan dalam pembelajaran operasi perkalian bilangan cacah, karena guru masih belum menggunakan pendekatan realistik. Guru dalam menyampaikan materi pelajaran operasi perkalian bilangan cacah dengan menggunakan metode ceramah dan guru terfokus pada buku paket yang ada. Seperti pada saat guru menjelaskan pembelajaran tentang perkalian siswa mengerti, tetapi setelah guru membuat sosal operasi perkalian bilangan cacah siswa mulai bingung. Hal ini menyebabkan rendahnya hasil pembelajaran siswa, untuk meningkatkan hasil pembelajaran matematika tergantung dari bagaimana guru melaksanakan pembelajaran. Guru harus menciptakan pembelajaran yang menyenangkan bagi siswa. Salah satu cara yaitu dengan menerapkan pendekatan matematika realistik. Dari hasil pengamatan tersebut, hal ini adalah merupakan masalah yang perlu diatasi. Oleh sebab itu perlu dikembangkan suatu pembelajaran yang tidak membosankan dan membuat siswa lebih tertarik, dengan cara menciptakan lingkungan belajar yang dekat dengan dunia nyata. Kegiatan pembelajaran pendekatan matematika realistik dapat mengarahkan siswa mengaplikasikan teori matematika secara bermakna.

Pembelajaran matematika dengan pendekatan matematika realistik, akan memberikan kesempatan kepada siswa untuk menemukan dan mengkonstruksi kembali konsep matematika sehingga siswa mempunyai konsep pengertian yang kuat. Hal tersebut dapat dilakukan dengan mengupayakan berbagai kondisi dan situasi serta permasalahan-permasalahan yang realistik, sehingga pembelajaran bermakna dan membuat siswa tertarik untuk belajar matematika serta dapat meningkatkan hasil pembelajaran. Pendekatan Realistik yang lebih dikenal dengan Realistic Mathematics Education (RME) pertama kali dikenalkan di Belanda pada tahun 1970 oleh Institut Freudenthal. RME pada dasarnya adalah pemanfaatan realitas dan lingkungan yang dipahami siswa untuk memperlancar proses pembelajaran matematika sehingga dapat mencapai tujuan pendidikan matematika secara lebih baik daripada masa yang lalu Soedjadi (2001:2). Dengan kata lain pembelajaran matematika dengan RME menuntut siswa untuk aktif membangun sendiri pengetahuannya dengan menggunakan dunia nyata untuk pengembangan ide dan konsep matematika. RME adalah suatu pendekatan pendidikan matematika yang dikembangkan di Netherland (Belanda) oleh Hans Freudental. Di dalam RME dunia nyata digunakan sebagai titik awal untuk pengembangan ide dan konsep matematika (Sutarto, 2005:19).

Sutarto (dalam Sugiman, 2000:168) mengemukakan tahap-tahap pembelajaran Matematika dengan pendekatan matematika realistik terdiri dari 4 tahap yaitu: (a) Tahap pendahuluan. Pada tahap ini pembelajaran dimulai dengan pemberian masalah real bagi siswa sesuai dengan pengalaman dan pengetahuan siswa agar pembelajaran lebih bermakna bagi siswa. Hal ini dimaksudkan supaya siswa terlibat dalam pembelajaran secara bermakna; (b) Tahap pengembangan model simbolik. Dalam tahap ini siswa masih dihadapkan pada masalah real. Siswa mengembangkan model sendiri dalam menyelesaikan masalah dari bentuk konkret ke abstrak; (c) Tahap penjelasan dan alasan. Pada tahap ini siswa diminta untuk memberikan alasan atas jawaban yang diberikan, jika jawaban yang diberikan siswa salah, maka guru dapat melemparkan pertanyaan pada siswa lain sehingga terjadi interaksi yang efektif dan guru berperan sebagai fasilitator dan motivator; dan (d) Tahap penutup. Pada tahap ini guru memberikan arahan pada siswa untuk mengumpulkan atau merangkum dari masalah dalam kehidupan sehari-hari yang telah dikerjakan siswa.

\section{METODOLOGI}

Penelitian ini dilaksanakan di kelas I SD Unggul Terpadu Padang Pariaman. Lokasi ini dipilih sebagai tempat penelitian dengan pertimbangan sebagai berikut: Pertama, guru cenderung menggunakan pembelajaran yang konvensional seperti metode ceramah dan tanya jawab. Kedua, belum pernah dilaksanakan pembelajaran pendekatan matematika realistik dalam pembelajaran matematika. Ketiga, siswa mengganggap matematika pelajaran yang membosankan dan sulit untuk dimengerti. Subjek dalam penelitian ini adalah siswa kelas I, yang 
terdaftar pada semester II tahun ajaran 2014/2015, dengan jumlah siswanya 25 orang. Jenis penelitian ini adalah penelitian tindakan kelas yaitu proses yang dilakukan perorangan atau kelompok yang menghendaki perubahan dalam situasi tertentu. Menurut Wardhani (2007:1.4) "Penelitian tindakan kelas adalah penelitian yang dilakukan oleh guru di dalam kelasnya sendiri malalui refleksi diri, dengan tujuan memperbaiki kinerjanya sebagai guru, sehingga hasil belajar siswa menjadi meningkat".

Penelitian ini di awali dengan adanya observasi awal/studi pendahuluan terhadap proses pembelajaran di SD Unggul Terpadu Padang Pariaman. Kegiatan ini dilaksanakan untuk mengetahui permasalahan yang dihadapi guru dan siswa yang berkaitan dengan proses pembelajaran matematika di kelas I SD Unggul Terpadu Padang Pariaman. Studi pendahuluan dilakukan dengan mengamati proses pembelajaran di kelas, diskusi dengan guru dan siswa tentang proses pembelajaran yang dilaksanakan selama ini. Kemudian peneliti dan guru merumuskan permasahan yang akan diangkat sebagai permasalahan penelitian yakni, peningkatan pembelajaran matematika melalui pendekatan matematika realistik pada siswa kelas I SD Unggul Terpadu Padang Pariaman.

Data penelitian berupa observasi, hasil tes, diskusi dan dokumentasi dari setiap tindakan perbaikan pembelajaran matematika melalui pendekatan matematika realistik siswa kelas I SD yang diteliti. Data tersebut berisi tentang hal-hal yang berkaitan dengan perencanaan, pelaksanaan, dan hasil pembelajaran yang berupa informasi berikut: (a) Pelaksanaan pembelajaran yang berhubungan dengan perilaku guru dan siswa yang meliputi intereksi belajarmengajar antara guru dan siswa, siswa dengan siswa, siswa dengan guru dalam proses pembelajaran matematika; (b) Evaluasi pembelajaran matematika yang berupa evaluasi proses maupun evaluasi hasil; (c) Hasil tes siswa dilaksanakan sesudah pelaksanaan tindakan pembelajaran matematika

\section{HASIL DAN PEMBAHASAN}

HASIL PENELITIAN

\section{Deskripsi Siklus I}

\section{a. Perencanaan}

Penggunaan pendekatan realistik dalam perencanaan pembelajaran matematika disusun dan diwujudkan dalam bentuk Rencana Pelaksanaan Pembelajaran (RPP). Perencanaan ini disusun berdasarkan program semester kedua sesuai dengan penelitian berlangsung. Perencanaan pembelajaran disusun untuk alokasi waktu 2 x pertemuan yaitu 5 x 35 menit. Materi diambil dari kurikulum SD 2006, Kurikulum Tingkat Satuan Pendidikan (KTSP) mata pelajaran matematika kelas I semester II.

\section{b. Pelaksanaan}

Siklus I dilaksanakan dalam 2 kali pertemuan. Setiap pertemuan terdiri atas tahap pendahuluan, tahap pengembangan model simbolik, tahap penjelasan dan alasan, dan tahap penutup.

\section{c. Pengamatan}

Pembelajaran pada pertemuan I siklus I ini diamati oleh kepala sekolah. Sedangkan proses pembelajarannya dilaksanakan oleh peneliti sendiri sebagai guru. Di mana kepala sekolah tersebut mengamati jalannya pelaksanaan pembelajaran dengan menggunakan lembar observasi guru dan siswa. Pengamatan ini dilakukan secara berkelanjutan mulai dari tindakan awal pada petemuan I sampai tindakan akhir pada petemuan II. Hal ini dikarenakan oleh pengamatan terhadap satu tindakan akan berpengaruh pada tindakan yang lainnya. Hasil pengamatan ini kemudian direfleksi untuk perencanaan pada siklus II.

Observasi keberhasilan tindakan diamati selama dan sesudah tindakan dilaksanakan. Hal ini dilaksanakan untuk mendapatkan informasi dari observer terhadap pelaksanaan pembelajaran pada siklus I baik pelaksanaan, evaluasi dan hasil yang diperoleh oleh siswa. Berdasarkan pengamatan observer hasil diskusi dengan peneliti, pada tindakan siklus I ditemukan masih ada siswa yang belum ikut secara aktif menyelesaikan masalah realistik yang diberikan. Selain itu juga ditemukan adanya beberapa siswa yang belum berani mengemukakan pendapatnya, siswa lebih suka mendengar dan memperhatikan temannya berdiskusi.

Keadaan kelas memang agak ribut dan waktu banyak terbuang untuk mengatur siswa dan siswa masih ada yang belum aktif mengikuti kegiatan pembelajaran secara individual dan pada kelompoknya. Namun demikian secara umum ditemukan bahwa siswa secara klasikal senang belajar dengan pendekatan realistik. Siswa lebih cepat memahami masalah dengan adanya kegiatan dan kebebasan dalam bekerja. Apalagi siswa diberi kesempatan bertanya dan memperhatikan kelompok lain untuk menyampaikan hasil evaluasi dan LKSnya. Dalam pembelajaran siswa terlihat senang jadi tidak mengantuk dan waktupun terasa cepat 
berlalu, sehingga tidak menimbulkan kejenuhan. Evaluasi hasil yang diperoleh pada siklus I mencapai $77,2 \%$. Hal ini disebabkan ada sebagian yang siswa masih mengalami kesulitan dalam menjawab soal mengenai perkalian dan pembagian dan mengenai operasi hitung campuran dalam pembelajaran melalui pendekatan matematika realistik.

\section{d. Refleksi}

Refleksi dilihat dari hasil paparan siklus I diketahui bahwa perencanaan pembelajaran terlaksana dengan cukup baik. Sebahagian dari langkah pada perencanaan terlaksana sesuai dengan yang diinginkan. Tapi terdapat beberapa langkah yang tidak berjalan baik. Contohnya, pada awal pembelajaran pertemuan II pembentukan kelompok menghabiskan waktu yang lama, peneliti kurang memberikan pengarahan tentang memindahkan masalah dalam bentuk matematika.

Dari hasil diskusi dengan guru kelas, maka diperoleh hal-hal sebagai berikut: (1) Secara umum pelaksanaan pembelajaran telah berjalan sesuai dengan rencana pembelajaran yang disusun karena telah mencerminkan model pendekatan realistik; (2) Belum semua siswa aktif, maka aktifitas siswa selama proses pembelajaran perlu ditingkatkan; (3) Guru perlu meningkatkan cara memotivasi siswa dalam mengeluarkan pendapat karena masih banyak siswa yang belum berani menanggapi hasil diskusi kelompok temannya; (4) Guru perlu membimbing siswa dalam menyimpulkan materi pembelajaran karena siswa banyak yang tidak membuat kesimpulan materi pelajaran; (5) Pembelajaran siklus I memerlukan waktu lebih dari waktu yang direncanakan, karena waktu banyak terpakai oleh pengaturan kelompok; (6) Pelaksanaan pembelajaran masih belum optimal, karena masih ada siswa yang belum paham memindahkan permasalahan kebentuk matematika; (7) Hasil tes akhir dan ketuntasan belajar siswa menunjukan lebih dari separoh siswa yang belum tuntas belajarnya. Masih ada beberapa siswa yang masih mendapatkan nilai di bawah rata-rata. Pada umumnya siswa mengalami kesulitan dalam langkah melakukan operasi hitung campuran. Setelah ditanyakan kepada siswa ternyata banyak yang menjawab tidak paham yang mana yang dikerjakan terlebih dahulu.

Berdasarkan refleksi di atas dan hasil diskusi dengan teman sejawat, pembelajaran yang diharapkan pada pembelajaran siklus I belum tercapai dengan baik. Upaya menggunakan pendekatan realistik dapat menentukan langkah-langkah proses pembelajaran yang akan ditargetkan pada siklus II. Untuk peningkatan aktivitas dan hasil belajar siswa agar sesuai dengan yang diharapkan maka perlu dirumuskan tindakan pada siklus II antara lain: (1) Memotivasi siswa agar aktif berdiskusi dalam kelompok; (2) Untuk menghemat waktu, siswa dikelompokan dengan teman sebangkunya dan ini juga bertujuan supaya siswa lebih aktif dalam melakukan kegiatan; (3) Lebih membimbing siswa untuk paham memindahkan permasalahan ke bentuk matematika; (4) Memotivasi siswa untuk menanggapi hasil diskusi kelompok temannya; (5) Membimbing siswa menyimpulkan materi pelajaran; (6) Siswa mampu mengerjakan evaluasi yang diberikan guru dengan baik dan benar.

Bersama observer peneliti mendiskusikan perencanaan untuk siklus berikutnya. Berdasarkan pengamatan, dan hasil tes maka tujuan yang diharapkan pada pembelajaran siklus I belum tercapai. Dengan demikian upaya menerapkan strategi pembelajaran berbasis masalah dapat direncanakan langkah-langkah proses pembelajaran yang akan ditargetkan pada siklus II. Dengan demikian rencana perbaikan ditargetkan pada kendala yang ditemui pada siklus I, dan akan dilaksanakan pada siklus II.

\section{Deskripsi Siklus II}

\section{a. Perencanaan}

Berdasarkan hasil tindakan dari siklus I yang telah diuraikan di atas maka pada siklus II ini tindakan yang akan dilaksanakan yakni: 1) memperjelas penyampaian tujuan pembelajaran agar siswa lebih memahami materi yang akan di ajarkan. 2) Memperbanyak media dan diberikan kepada semua anggota kelompok sehingga masing-masing anggota kelompok dapat membaca dan memahami isi LKS dengan baik. 3) Masing-masing siswa dalam kelompok melakukan percobaan untuk penyelidikan. 4) Berusaha memaksimalkan pemakaian waktu dalam pembelajaran sesuai dengan rencana pembelajaran. 5) lebih memotivasi siswa agar dapat ikut aktif berdiskusi dalam kelompok.

\section{b. Pelaksanaan}

Siklus II juga dilaksanakan dalam 2 kali pertemuan. Setiap pertemuan terdiri atas tahap pendahuluan, tahap pengembangan model simbolik, tahap penjelasan dan alasan, dan tahap penutup. 


\section{c. Pengamatan}

Evaluasi hasil yang diperoleh pada siklus II mencapai rata-rata $88 \%$ dengan perincian sebagai berikut: 8 siswa (32\%) yang memperoleh nilai 100, 6 siswa (24\%) yang meperoleh nilai 90, 5 siswa (20\%) yang memperoleh nilai 85,3 pserta didik (12\%) yang memperoleh nilai 80,2 siswa (8\%) yang mendapat nilai 70, 1 siswa (4\%) yang memperoleh nilai 60. Ini berarti lebih dari $85 \%$ dari jumlah siswa yang mendapat nilai diatas 75 (88\% dari jumlah siswa). Data hasil belajar siswa pada siklus II dapat dilihat pada lampiran 26. Evaluasi hasil yang diperoleh pada siklus II $(88,2)$ mengalami peningkatan dibandingkan dengan tes pada siklus I $(77,2)$.

\section{d. Refleksi}

Kegiatan refleksi dilakukan secara kolaboratif antara peneliti, kepala sekolah setiap pembelajaran berakhir. Pada kesempatan ini temuan dan hasil pengamatan peneliti dibahas bersama. Refleksi tindakan siklus II ini mencakup refleksi terhadap perencanaan, pelaksanaan, evaluasi dan hasil yang diperoleh oleh siswa. Refleksi terhadap perencanaan yakni sebagai berikut: dilihat dari paparan siklus II diketahui bahwa perencanaan pembelajaran sudah lebih baik dari siklus I, serta dilaksanakan sesuai dengan langkah-langkah yang tertulis dalam perencanaan. Dari hasil belajar siswa yang meningkat, karena tidak ditemukan lagi siswa yang memperoleh nilai dalam $<70$. Nilai anak hanya berkisar di atas 70-100 dengan nilai rata-rata siswa 88. Jadi, dapat disimpulkan bahwa penelitian dalam pembelajaran siklus II telah melaksanakan tugas dengan baik. Dengan demikian penelitian ini berhenti pada siklus II dan tidak dilanjutkan pada siklus berikutnya.

\section{PEMBAHASAN}

\section{Siklus I}

Dari hasil penelitian pelaksanaan pembelajaran pendekatan matematika realistik pada pembelajaran melakukan operasi hitung campuran perkalian dan pembagian bilangan sampai dua angka pada mata pelajaran matematika kelas I Sekolah Dasar Unggul Terpadu Padang Pariaman. Dan terlihat dalam proses pembelajaran bahwa guru membuat rancangan pembelajaran dalam bentuk Rencana Pelaksanaan Pembelajaran (RPP). Rencana Pelaksanaan Pembelajaran merupakan rencana operasional pembelajaran yang memuat beberapa indikator yang terkait untuk dilaksanakan dalam satu atau beberapa kali pertemuan”.

Berdasarkan perencanaan yang disusun pelaksanaan pembelajaran dilaksanakan sesuai dengan apa yang telah direncanakan, yang mana pada siklus I pembelajaran disajikan dalam dua kali pertemuan (5x35menit). Pembelajaran pada siklus I dilaksanakan sesuai dengan tahap-tahap pembelajaran matematika realistik yaitu: 1) tahap pendahuluan, 2) tahap pengembangan model simbolik, 3) tahap penjelasan dan alasan, dan 4) tahap penutup. Berdasarkan catatan pada lembar observasi dan diskusi peneliti dengan pengamat penyebab dari masih rendahnya hasil belajar siswa pada siklus I secara garis besar adalah masih banyak siswa yang belum aktif dalam pembelajaran.

Setelah diperhatikan data hasil penelitian yang berkaitan dengan evaluasi pembelajaran, evaluasi yang dilakukan adalah evaluasi proses dan evaluasi hasil. Evaluasi proses pada setiap siklus dilakukan guru pada saat siswa berdiskusi. Berdasarkan hasil observasi aktivitas guru dan siswa dan diskusi peneliti dengan teman sejawat dan observer di atas, penyebab dari adanya siswa yang belum dapat menyelesaikan operasi hitung campuran disebabkan karena pembelajaran yang kurang menyenangkan dan guru kurang mengkonkretkan pembelajaran serta kurang melibatkan siswa dalam kegiatan pembelajaran operasi hitung campuran. Adapun belajar dengan kolaboratif secara langsung, dapat mendekatkan siswa pada situasi belajar yang diinginkan, membantu siswa kearah perkembangan kognitifnya. Dengan kegiatan ini, siswa mampu berlatih dan berbagi pengalaman, melatih keberanian mengeluarkan pendapat, dan bersedia mendengarkan.

Berdasarkan hasil pengamatan aktivitas guru, guru kurang memberikan motivasi kepada siswa untuk menyampaikan ide/gagasan yang ditemukannya. Guru juga kurang membimbing siswa dalam menyimpulkan materi pelajaran. Oleh sebab itu sebaiknya gurulah lebih memotivasi dan membimbing siswa untuk menyampaikan ide/gagasan yang mereka temukan dalam melakukan operasi hitung campuran. Guru harus membimbing siswa untuk membuat simpulan pembelajaran dan membimbing siswa untuk dapat memindahkan permasalahan dalam matematika. Hal ini karena siswa baru pertama kali melaksanakan pembelajaran seperti ini. 


\section{Siklus II}

Rencana Pelaksanaan Pembelajaran (RPP) pada siklus II ini hampir sama dengan siklus I, namun dalam tahap penyelidikan, pengembangan materi, media yang digunakan dalam penyelidikan lebih dimaksimalkan. Pembelajaran melakukan operasi hitung campuran perkalian dan pembagian bilangan sampai dua angka dengan menggunakan pendekatan matematika realistik pada siklus II ini sudah berjalan dengan baik. Pembelajaran dipengaruhi oleh berbagai faktor seperti motivasi, kematangan, hubungan siswa dengan guru, kemampuan verbal, tingkat kebebasan, rasa aman, dan keterampilan guru dalam berkomunikasi. Oleh karena itu guru harus melakukan perbaikan dalam pelaksanaan pembelajaran disamping perbaikan pada RPP. Guru harus dapat memberikan motivasi kepada siswa dalam pembelajaran. Dari hasil analisis penelitian siklus II sudah mencapai $88 \%$ dan nilai rata-rata kelas 88,2 . Berdasarkan hasil pengamatan siklus II yang diperoleh maka pelaksanaan siklus II sudah baik dan guru sudah berhasil dalam usaha peningkatan hasil belajar matematika tentang operasi hitung campuran melalui pendekatan realistik bagi kelas I SD Unggul Terpadu Padang Pariaman.

Pembelajaran yang disajikan guru dalam memberikan motivasi dan bimbingan kepada siswa sangat bagus. Apalagi dengan guru menggunakan model pembelajaran realistik dimana model ini membuat siswa merasa senang, karena masalah yang mereka kerjakan berhubungan dengan kehidupan sehari-hari dan siswa dilibatkan dalam melakukan kegiatan pembelajaran. Di samping itu, guru juga memberi kesempatan kepada siswa untuk mengemukakan ide-ide yang telah mereka temukan dalam menyelesaikan permasalahan yanng diberikan. Untuk itu guru harus mampu menciptakan situasi yang menyenangkan untuk belajar.

Pada dasarnya, matematika adalah pemecahan masalah (problem solving), oleh sebab itu matematika sebaiknya diajarkan melalui berbagai masalah yang ada di lingkungan sekitar siswa. Dengan begitu siswa dapat terlatih berfikir dan berargumentasi. Melalui matematika, siswa dapat pula dibiasakan bekerja efisien, selalu berusaha mencari jalan yang lebih sederhana dan lebih mudah dipahaminya tanpa mengurangi keefektifannya. Untuk mencapai hal tersebut sudah seharusnya guru mampu menciptakan pembelajaran yang sesuai dengan kebutuhan siswa. Selain itu guru juga harus memperhatikan keberhasilan siswa dalam memahami sesuatu dengan cara sesuai dengan tingkat kemampuan siswa. Guru bertugas membelajarkan siswa, maka guru haruslah menggunakan berbagai macam cara agar pembelajaran dapat bermakna bagi siswa, seperti menggunakan pendekatan realistik, dimana siswa terlibat dalam melakukan kegiatan pembelajaran dan siswa menemukan sendiri konsep matematika. Pendekatan realistik dapat menciptakan suasana belajar yang menyenangkan bagi siswa.

\section{SIMPULAN DAN SARAN}

Berdasarkan pada paparan data, hasil penelitian dan pembahasan tentang pembelajaran matematika dengan menggunakan pendekatan matematika realistik, maka dapat disimpulkan sebagai berikut: (1) Pembelajaran matematika melalui pendekatan realistik terdiri dari 4 tahap. Pembelajaran menggunakan pendekatan realistik dibagi atas tiga kegiatan yaitu kegiatan awal, kegiatan inti, kegiatan akhir. Pada kegiatan awal dilaksanakan kegiatan tahap pendahuluan dan membagi kelompok. Pada kegiatan inti dilaksanakan tahap pengembangan model simbolik dan tahap penjelasan dan alasan. Pada kegiatan akhir dilaksanakan tahap penutup dimana siswa diarahkan untuk menyimpulkan pembelajaran dan memberikan tes akhir; (2) Pendekatan realistik dapat memotivasi siswa untuk belajar dengan gembira, bebas, aktif, dan produktif, sehingga kendala psikologis yang sering menghambat siswa seperti rasa enggan, segan, takut, dan malu dapat teratasi; (3) Siswa terlatih berbagi pengalaman, aktif dalam belajar, berani menyampaikan ide/gagasan yang ditemukannya, dan bersedia mendengarkan pendapat orang lain, serta mau menerima perbedaan pendapat; (4) Fungsi guru berubah dari seorang penyampai pengetahuan atau pemberi informasi menjadi fasilitator. Hal ini terlihat dalam penyajian pembelajaran guru yang semula selalu memberi penjelasan berubah menjadi fasilitator; dan (5) Bentuk pembelajaran dengan pendekatan realistik terhadap operasi hitung campuran dapat meningkatkan hasil belajar siswa. Meningkatnya hasil belajar siswa tersebut dapat dilihat dari rata-rata yang diperoleh pada siklus I yakni 77,2 dan pada siklus II mengalami peningkatan yaitu menjadi 88,2.

Berdasarkan kesimpulan yang telah diperoleh dalam penelitian ini, diajukan beberapa saran untuk dipertimbangkan: (1) Bentuk pembelajaran matematika melalui pendekatan realistik layak dipertimbangkan oleh guru untuk menjadi pembelajaran alternatif yang dapat digunakan sebagai referensi dalam memilih pendekatan pembelajaran; (2) Bagi guru yang ingin menerapkan pembelajaran dengan menggunakan pendekatan realistik, 
disarankan memperhatikan hal-hal seperti materi pembelajaran yang kontekstual, kreatifitas dalam merancang pembelajaran yang sesuai dengan situasi dunia nyata, memberikan bimbingan dan motivasi belajar secara sungguh-sungguh kepada siswa yang berkemampuan kurang dan pasif dalam kelompok; (3) Guru perlu menyiapkan sarana dan prasarana yang dikenali siswa, karena akan mempermudah siswa memahami masalah; (4) Bagi peneliti selanjutnya disarankan untuk melakukan kajian mendalam tentang penerapan model pembelajaran dengan pendekatan realistik pada materi lain dalam matematika; dan (5) Kepada kepala Sekolah Dasar dan pejabat terkait kiranya dapat memberikan perhatian kepada guru terutama dalam meningkatkan hasil belajar dalam proses pembelajaran.

\section{DAFTAR RUJUKAN}

Arjuna, Abang. (2007). Matematika Realistik. (Online) (http://darmosusianto.blogspot.com/2007/08/Matematikarealistik.html di akses 5 Maret 2009).

Buyung. (2006). Peningkatan Pemahaman Terhadap Konsep Volume Balok Melalui Pendekatan matematika realistik Bagi Siswa Kelas V SD. PGSD.UNP.

Depdiknas. (2006). Kurikulum Tingkat Satuan Pendidikan Jenjang Pendidikan Dasar. Jakarta: Depdikan.

Gravemeijer. (1994). Developing Realitics Mathematics Education. Freudenthal institute. Utrecht.

Sardiman, A, M. (2006). Interaksi dan Motivasi Belajar-Mengajar. Jakarta: PT Raja Grafindo Persada.

Suharsimi, Arikunto, dkk. (2006). Penelitian Tindakan Kelas. Jakarta: Bumi Aksara .

Sutarto, Hadi. (2007). Pendidikan Matematika Realistik. Banjarmasin: Tulip.

Zainure. (2007). Pembelajaran Matematika Realistik (RME). (Online) (http://zainurie.wordpress.com/2007/04/13/pembelajaran-Matematika-realistik-rme/ diakses tgl 2 Maret 2009). 